FON ; Jurnal Pendidikan Bahasa dan Sastra Indonesia

Volume 12 Nomor 1 Tahun 2018

\title{
ANALISIS PENERJEMAHAN KATA-KATA SLANG DALAM HASIL PENERJEMAHAN FILM “AUSTIN POWER; THE SPY WHO SHAGGED ME"
}

\author{
Muhammad Aprianto Budie Nugroho \\ Program Studi Pendidikan Bahasa Inggris, Universitas Kuningan, Indonesia \\ Pos El.muh.apriantobn@gmail.com
}

\begin{abstract}
ABSTRAK
Penelitian ini bertujuan menganalisis penerjemahan kata-kata slang dan kesetaraan penerjemahan yang dilakukan oleh mahasiswa dalam menerjemahan karya sastra berupa film berjudul, “Austin Powers; The Spy who Shagged Me”. Peneliti menggunakan metode qualitatif. Peneliti menggunakan beberapa langkah dalam penelitian mulai dari pengumpulan yaitu berupa observasi data dan menganalisis dokumen data. Dalam menganalisis penerjemahan yang dilakukan oleh mahasiswa peneliti menggunakan teori Newman dan dalam menganalisis kesetaraan dalam penerjemahan peneliti menggunakan teori Baker. Dalam penelitian ini diketemukan fakta bahwa mahasiswa mampu menerjemahkan 6 kata slang dari 12 kata slang yang terdapat dalam film berjudul, "Austin Power; The Spy Who Shagged Me”, sedangkan dalam kesetaraan penerjemahan terdapat 3 kesetaraan yang digunakan dalam menerjemahkan dari 3 jenis kesetaraan yang ada.
\end{abstract}

Kata kunci: Penerjemahan, Film, Kata-kata slang, Kesetaraan penerjemahan

\section{PENDAHULUAN}

Peranan penerjemahan dalam kehidupan kita sangatlah penting terutama dalam kerangka pembangunan manusia Indonesia seutuhnya. Kemajuan dan perkembangan negara kita tidak lagi akan bergantung pada sumber daya alam yang kian hari kian menyusut, namun akan selalu bergantung pada kualitas manusianya. Peningkatan kualitas manusia ini hanya akan dapat dilakukan apabila ilmu pengetahuan dan kerekayasaan telah menjadi milik kita. Padahal, sperti sudah diketahui, perkembangan ilmu pengetahuan dan kecanggihan teknologi dilaporkan dalam 
FON ; Jurnal Pendidikan Bahasa dan Sastra Indonesia

Volume 12 Nomor 1 Tahun 2018

bahasa asing, khususnya bahasa Inggris.

menerjemahkan harus diberikan kepada

Disinilah pentingnya dilakukan

para mahasiswa Universitas terutama

penerjemahan ilmu pengetahuan dan

dimana mahasiswa mendalami

teknologi dari bahasa Inggris kedalam pembelajaran bahasa Inggris. Hal tersebut bahasa Indonesia.

Terminologi penerjemahan merujuk sangat penting sehingga mahasiswa mempunyai kemampuan yang pada penghilangan refleksi dan ide-ide dari satu bahasa sumber yang menerjemahkan yang baik. diterjemahkan ke dalam bahasa target. Penerjemahan adalah sebuah aktivitas ketika seseorang penerjemah/translator menerjemahkan ke dalam bahasa target secara akurat. Akurasi sangat dibutuhkan dalam proses dalam penerjemahan dengan tujuan untuk menghasilkan sebuah hasil penerjemahan yang bagus dan akurat. Catford (1962:20) Dengan mengganti materi textual di dalam sauatu bahasa (Bahasa Sumber) dengan materi textual yang equivalent di dalam bahasa target. Dalam menerjemahkan, seorang penerjemah diharapkan tidak hanya menerjemahkan sebuah text dari bahasa sumber kedalam bahasa target, seorang penerjemah dituntut untuk memahami budaya dari bahasa sumber, sehingga hasil penerjemahannya akan natural.

Abdul Rosyid (2011) menyatakan bahwa bahasa Inggris dan Indonesia mempunyai latar belakang budaya yang berbeda dan mempengaruhi bahasa target. Untuk alasan tersebut, keampuan Seperti yang bisa di lihat saat ini, karya-karya sastra asing adalah salah satu produk yang banyak diterjemahkan ke dalam bahasa Indonesia. Penerjemahan yang dilakukan utuk karya-karya sastra membutuhkan kemampuan menerjemahkan yang baik, dan pemahaman mengenai budaya dan kebiasaan dari bahasa asal yang kemudian diterjemahkan ke dalam bahasa target, yang tentunya harus disesuaikan dengan budaya dan adat istiadat dari bahasa target. Penerjemahan di lakukan pada karya sastra tidak hanya menerjemahkan kata demi kata saja tetapi juga harus menyesuaikan dengan bahasa target.

Di dalam karya-karya sastra terdapat kata-kata yang dikategorikan dalam bahasa slang. Bahasa slang adalah variasi bahasa yang digunakan oleh sekelompok orang tertentu, sehingga terkadang dapat menimbulkan kebingungan. Terdapat beberapa diskusi mengenai definisi akurat dari "slang" dan bagaimana digunakan. Slang adalah penggunaan kata-kata yang 
FON ; Jurnal Pendidikan Bahasa dan Sastra Indonesia

Volume 12 Nomor 1 Tahun 2018

tidak standar dalam bahasa. Dalam McCullers, dan dibantu oleh Mike Myers. bukunya spolsky (1998) menyatakan Film ini dibintangi oleh Mike Myers yang bahwa slang adalah cara bicara yang uniknya berperan sebagai tiga tokoh yaitu; spesifik diklaim oleh kelompok tertentu, Austin Powers, Dr. Evil, dan Fat Bastard. bukti keanggotaan, dan untuk menolak Film ini adalah versi komedi dari filmdimensi kekuasaan yang diasosiasikan film genre aksi seperti James Bond. Film dengan bahasa formal. Slang biasa ini berkisah mengenai seorang agen yang ditemukan dalam produk sastra terutama mojonya dicuri oleh salah satu tokoh jahat pada film-film Holywood bergenre yaitu Fat Bastard yang merupakan komedi. Menurut Klarer (2004) bahwa suruhan Dr. Evil. Austin berusaha film dikategorikan sebagai bagian dari merebut kembali mojo-nya serta performing arts karena film melibatkan menyelamatkan dunia dari kejahatan Dr. aktor dalam Evil yang berusaha memeras para menyampaikan/mengekspresikan gagasan. pemimpin negara dengan ancaman akan Selain itu dia menambahkan bahwa film mempunyai kekuatan visual dan menghancurkan kota-kota besar di dunia.

Didalam penelitian ini peneliti akan membutuhkan presentasi yang lebih menganalisis hasil penerjemahan para seperti angle kamera, editing, gerakan mahasiswa di tingkat 3 , semester 5 di cepat dan lambat, direkam dengan suara yang menceritakan mengenai cerita Prodi Pendidikan Bahasa Inggris, FKIP, Universitas Kuningan. Peneliti tertentu. Terdapat beberapa jenis genre memfokuskan analisa pada hasil film yaitu; aksi, petualangan, komedi, penerjemahan mahasiswa terutama pada drama, komedi-drama, horror, fantasi, kata-kata slang yang terdapat pada dialog roman, thriller, animasi, keluarga dll.

Film berjudul "Autin Power; The antar tokoh di dalam film tersebut. Penelitan-penelitian mengenai Spy Who Shagged Me" termasuk dalam penerjemahan slang pernah dilakukan genre film aksi-komedi yang merupakan sebelumnya, salah satunya adalah film sekuel terdahulu yaitu "Austin penelitian yang dilakukan oleh Yuliana Power: International Man of Mystery (2014) yang meneliti mengenai (1997)" dan "Austin Power in Gold penerjemahan kata slang bahasa ingris Member. Film ini disutradarai oleh Jay dalam novel yang ditulis Shidney Sheldon Roach, naskahnya ditulis oleh Michael berjudul "Nothing Last Forever". Didalam 
FON ; Jurnal Pendidikan Bahasa dan Sastra Indonesia

Volume 12 Nomor 1 Tahun 2018

penelitiannya berdasarkan data 65 kata, kelasnya terdiri dari 6 kelas, dengan terdapat 12 kata slang terdapat dalam jumlah mahasiswa 285 mahasiswa, telah novel tersebut.

meluluskan kurang lebih dari 1000 mahasiswa hingga saat ini.

\section{METODE PENELITIAN}

Di dalam penelitian ini Partisipan di dalam penelitian ini menggunakan metode penelitian kualitatif, menurut Creswell (1988, p.15) bahwa penelitian kualitatif adalah sebuah proses penyelidikan untuk memahami berdasarkan perbedaan tradisi metodologi penelitian dalam mengeksplorasi sebuah sosial atau permasalahan manusia. Peneliti membangun sebuah pandangan yang komplek, gambaran holistik, analisis katakata, detail laporan dilihat dari informan dan tindakan yang natural atau alami.

Darlington dan Scott (2003, p.3) menambahkan bahwa penelitian kualitatif adalah bagaimana peneliti membangun pertanyaan, dan mengerjakan melalui daerah yang terjal baik secara etika dan politik, secara sistematik mengumpulkan data yang sesuai, menganalisisnya secara kaku dan menyebarkan hasil temuan dan implikasi dari penelitian.

Penelitian ini akan mengambil tempat di Universitas Kuningan tepatnya di program studi Pendidikan Bahasa Inggris, di Fakultas Keguruan dan Ilmu Pendidikan. Pendidikan bahasa Inggris didirikan pada tahun 2006, jumlah adalah 5 mahasiswa Prodi Pendidikan Bahasa Inggris pada tingkat 3, semester 5. Pemilihan partisipan didasarkan pada alasan bahwa mahasiswa pada tingkat ini sudah mendapatkan mata kuliah penerjemahan, sehingga dianggap mampu untuk menerjemahkan teks yang tingkat kesulitannya tinggi

Tekhnik pengumpulan data berdasarkan pada hasil observasi yang dilakukan serta dari dokumen yang di dapatkan melalui karya penerjemahan participant yang terlibat dalam penelitian ini.

\section{HASIL PENELITIAN}

Berdasarkan hasil klasifikasi dan analisis naskah percakapan dalam film "Austin Powers: The Spy Who Shagged Me" terdapat kurang lebih 16 kata slang terdapat pada percakapan diantara tokohtokoh yang terdapat dalam film tersebut, kata tersebut adalah: Dick, Pecker, Jhonson, Private, , willie, Jack-ass, the mojo, Spuds, prick, wang, rod, tallywhaker, wanker, schlong and tities. Kata- kate tersebut dalam kamus bahasa inggris slank mempunyai makna alat vital 
FON ; Jurnal Pendidikan Bahasa dan Sastra Indonesia

Volume 12 Nomor 1 Tahun 2018

laki-laki dan payudara perempuan dan diterjemahkan oleh para partisipan dalam bodoh. penelitian ini.

Berikut ini adalah hasil

penerjemahan kata-kata slang yang

Tabel 1. Hasil penerjemahan kata-kata slang

\begin{tabular}{|l|l|l|l|l|l|l|}
\hline No & $\begin{array}{l}\text { Bahasa } \\
\text { Sumber }\end{array}$ & \multicolumn{1}{|c|}{ P1 } & \multicolumn{1}{|c|}{ P2 } & \multicolumn{1}{|c|}{ P3 } & \multicolumn{1}{|c|}{ P5 } \\
\hline 1 & Dick & $\begin{array}{l}\text { Burung } \\
\text { pelatuk }\end{array}$ & Penis besar & $\begin{array}{l}\text { Mata- } \\
\text { mata }\end{array}$ & penis & penis \\
\hline 2 & Pecker & $\begin{array}{l}\text { Burung } \\
\text { pelatuk }\end{array}$ & pelatuk & $\begin{array}{l}\text { Burung } \\
\text { pelatuk }\end{array}$ & $\begin{array}{l}\text { Burung } \\
\text { pematuk }\end{array}$ & $\begin{array}{l}\text { Burung } \\
\text { pematuk }\end{array}$ \\
\hline 3 & Private & Prajurit & Prajurit & $\begin{array}{l}\text { Alat } \\
\text { kelamin }\end{array}$ & $\begin{array}{l}\text { Alat } \\
\text { kemaluan }\end{array}$ & $\begin{array}{l}\text { Alat } \\
\text { kemaluan }\end{array}$ \\
\hline 4 & Johnson & Johnson & Johnson & Johnson & Johnson & Johnson \\
\hline 5 & Titties & Payudara & Dada & Puting & puting & Payudara \\
\hline 6 & Willie & Melakukan & kegelisahanku & - & penisku & penisku \\
\hline 7 & Jack-ass & Bodoh & Sialan & Brengsek & Brengsek & Brengsek \\
\hline 9 & Spuds & Kentangku & Kentangku & - & - & - \\
\hline 10 & Prick & $\begin{array}{l}\text { Gangguan } \\
\text { kecil }\end{array}$ & $\begin{array}{l}\text { Gangguan } \\
\text { kecil }\end{array}$ & Burung & Burung & Burung \\
\hline 11 & Wang & Wang & Wang & Wang & Wang & Wang \\
\hline 12 & Rod & Rod & Rod & Rod & Rod & Rod \\
\hline
\end{tabular}

Naskah pertama yang diterjemahkan

Pilot : take look at starboard!!

adalah naskah percakapan yang terjadi antara pilot dan kopilot Amerika Serikat ketika mereka melihat sebuah roket Co-pilot $\quad$ : Oh my God, it look like a huge...... berbentuk aneh melewati mereka, Di dalam menerjemahkan dialog percakapan mereka sebagai berikut:

Pilot : Dick!!

tersebut diatas para partisipan dari penelitian ini menerjemahkan kata slang tersebut berbeda-beda. Didalam teks Co-Pilot : yes.. tersebut kata "Dick" tersebut selain 
merujuk pada nama panggilan seseorang, kata "Dick" juga merujuk pada sebuah kata slang yang berarti alat vital dari seorang lelaki. Didalam hasil penerjemahan yang dilakukan oleh partisipan 1 adalah sebagai berikut:

Pilot

\section{: burung pelatuk!}

Co-pilot : ya!!

Pilot : coba lihat sisi bagian kanan!!

Co-pilot : ya Allah, ini besar sekali..

Di dalam penerjemahan yang dilakukan oleh partisipan 1, dia menerjemahkan kata "Dick" dengan menerjemahkan kata slang tersebut dengan menggunakan kata "burung pelatuk". Partisipan 1 menggunakan kata tersebut untuk menerjemahkan kata tersebut, walaupun kata tersebut kurang tepat dalam menerjemahkan kata tersebut partisipan 1 cukup memahami makna/arti dari kata tersebut.

Sedangkan dalam penerjemahan yang dilakukan oleh partisipan 2 adalah sebagai berikut:

Pilot

\section{: mata-mata!}

Co-pilot : iya..

Pilot

: lihat ke sebelah kanan

Co-pilot : ya tuhan, itu terlihat sangat besar....

Di dalam hasil penerjemahan yang dilakukan oleh partisipan 2, bisa dilihat bahwa penerjemah 2 menggunakan kata "mata-mata" dalam menerjemahkan kata "Dick". Penggunaan kata "mata-mata" untuk menerjemahkan kata "Dick" tersebut kurang tepat dalam menerjemahkan kata slang tersebut.

Di dalam penerjemahan lain yang dilakukan oleh partisipan 3 dalam menerjemahkan kata slang didalam percakapan tersebut adalah sebagai berikut :

Pilot : Penis besar!!

Ko-Pilot : ya.....

Pilot

: lihat sebelah kanan

Co-pilot : ya tuhan itu terlihat seperti....

Di dalam hasil penerjemahan yang dilakukan oleh partisipan 3 , bisa dilihat bahwa partisipan 3 menggunakan kata "penis besar" dalam menerjemahkan kata "dick". Didalam penerjemahan ini partisipan 3 telah paham dengan makna /arti dari kata "dick" tapi kurang tepat dalam menggunakan kata "penis besar" dalam menerjemahkan kata tersebut.

Didalam penerjemahan lain yang dilakukan oleh partisipan 4 dalam menerjemahkan dialog tersebut adalah sebagai berikut:

Pilot : penis!!

Co-pilot : lihatlah keluar!! 
FON ; Jurnal Pendidikan Bahasa dan Sastra Indonesia

Volume 12 Nomor 1 Tahun 2018

Pilot : oh tuhan itu terlihat

Didalam naskah tersebut juga seperti.....

terdapat percakapan antara seorang suami-

Di dalam penerjemahan yang istri yang didalam film tersebut dilakukan oleh partisipan 4 , bisa dilihat digambarkan sedang mengamati burung bahwa partisipan 4 memilih menggunakan ketika mereka melihat sebuah roket kata "penis" dalam menerjemahkan kata "Dick" penggunaan kata "penis" dalam dengan bentuk yang aneh melintas di atas mereka, percakapan itu adalah sebagai menerjemahkan kata "Dick" oleh berikut: partisipan 4 menunjukan bahwa partisipan 4 memahami makna/arti dari kata tersebut namun penggunaan kata penis tersebut kurang tepat.

Didalam penerjemahan lain yang dilakukan oleh partisipan 5 dalam menerjemahkan dialog tersebut adalah sebagai berikut:

Pilot

\section{: Sialan!}

Co-Pilot : iya...

Pilot : liat keluar!!

Co-Pilot : oh Tuhan itu terlihat seperti.....

Dari hasil penerjemahan yang dilakukan oleh partisipan 5 bisa dilihat bagaimana partisipan menggunakan kata "Sialan" dalam menerjemahkan kata "Dick". Penggunaan kata "Sialan" dalam menerjemahkan kata "Dick" cukup menarik karena kata "Sialan" sendiri merupakan kata umpatan yang kurang tepat apabila digunakan dalam menerjemahkan kata tersebut.

\section{Man : Pecker!! \\ Woman : where?}

Man : over there. A rare red-billed woodpecker.

Woman : what sort of bird is that? Ooh goodness, it's not a bird, it's

Di dalam dialog tersebut penyebutan kata pecker itu sendiri mempunyai dua makna/arti yang berbeda, makna "Pecker" sendiri dalam bahasa Indonesia bisa disebut dengan "burung pelatuk", tetapi selain maknanya sebagai "burung pelatuk", kata pecker sendiri adalah kata slang yang mempunyai makna sebagai bagian vital dari lelaki.

Di dalam hasil penerjemahan yang dilakukan oleh para partisipan yang terlibat dalam penelitian ini menerjemahkan kata "Pecker" hampir semua partisipan menerjemahkan kata tersebut dengan kata yang sama. Hasil 
FON ; Jurnal Pendidikan Bahasa dan Sastra Indonesia

Volume 12 Nomor 1 Tahun 2018

penerjemahan dari kata tersebut bisa bisa dilihat bahwa penerjemah tidak dilihat sebagai berikut:

$\begin{array}{ll}\text { Lelaki } & : \text { Burung Pelatuk } \\ \text { Wanita } & : \text { dimana? } \\ \text { Lelaki } & : \text { sebelah sana, sebuah } \\ & \text { burung pelatuk langka }\end{array}$

Wanita : burung macam apa itu?

Ya Allah, itu bukan burung, ini adalah...

Di dalam penerjemahan tersebut bisa dilihat bahwa partisipan 1 menggunakan kata "burung pelatuk" dalam menerjemahkan kata "pecker". Penggunaan kata "burung pelatuk" kurang tepat dalam menerjemahkan kata slang dari "pecker".

Di dalam menejemahkan dialog tersebut, partisipan 2 menerjemahkan dialog antara sepasang suami-istri tersebut sebagai berikut:

$\begin{array}{lc}\text { Lelaki } & \text { : Pelatuk!! } \\ \text { Wanita } & \text { : dimana? } \\ \text { Lelaki } & \text { : diatas sana, seekor burung } \\ & \text { pelatuk berparuh merah. }\end{array}$

Wanita : burung macam apa itu? Ya ampun, itu bukan seekor burung, itu..

Di dalam penerjemahan tersebut bisa dilihat bahwa partisipan 2 menggunakan kata "pelatuk" dan "burung pelatuk" dalam menerjemahkan kata “pecker”. Di dalam penerjemahan tersebut menangkap makna dari ungkapan slang dari "pecker" sehingga menerjemahkan secara literal.

Di dalam penerjemahan lain yang dilakukan oleh partisipan 4 menggunakan kata yang serupa dalam menerjemahkan kata yang sama. Hal tersebut bisa dilihat dari hasil penerjemahan dibawah ini:

Lelaki

Wanita

Lelaki

berparuh merah yang
langka

Wanita

: burung jenis apa itu? Ooh tuhan itu bukan burung itu...

Dalam penerjemahan yang dilakukan oleh partisipan 4 terhadap kata slang "pecker" sangat menarik karena partisipan 4 menggunakan dua kata yang berbeda dalam menerjemahkannya. Di baris pertama dialog partisipan menggunakan kata "burung pematuk" dan di baris selanjutanya dia menggunakan "burung pematuk," dalam penerjemahan dialog ini partisipan 4 juga tidak mengetahui bahwa "pecker" sendiri mempunyai makna selain "burung pematuk"

Di dalam penerjemahan yang dilakukan oleh partisipan 5 juga 
FON ; Jurnal Pendidikan Bahasa dan Sastra Indonesia

Volume 12 Nomor 1 Tahun 2018

ditemukan kesamaan dalam para pembaca ketika para pembaca menerjemahkan kata "pecker" kedalam membaca teks yang telah diterjemahkan bahasa Indonesia, berikut ini adalah hasil dan dibandingkan dengan teks aslinya dari penerjemahan partisipan 5:

$\begin{array}{ll}\text { Lelaki } & \text { : Burung pematuk } \\ \text { Wanita } & \text { : dimana } \\ \text { Lelaki } & : \text { disana, burung pelatuk } \\ & \text { berparuh merah yang } \\ & \text { langka }\end{array}$

Di dalam penerjemaha yang dilakukan oleh partisipan 5 terlihat bahwa partisipan 5 menerjemahkan kata "pecker" dengan "burung pematuk" yang kemudian di alinea dialog berikutnya dia menggunakan kata "burung pelatuk" untung menerjemahkan kata "pecker". Terdapat inkosistensi yang dilakukan oleh partisipan 5 dalam menerjemahkan kata "pecker", selain itu partisipan 5 belum memahami makna kata tersebut yang merupakan kata slang.

Kesetaraan dalam penerjemahan menjadi perhatian pertama terutama bagi Tabel 2 Kesetaraan dalam penerjemah

\begin{tabular}{|c|l|c|c|c|c|c|c|}
\hline NO & Kesetaraan & $\begin{array}{c}\text { Partisipan } \\
\mathbf{1}\end{array}$ & $\begin{array}{c}\text { Partisipan } \\
\mathbf{2}\end{array}$ & $\begin{array}{c}\text { Partisipan } \\
\mathbf{3}\end{array}$ & $\begin{array}{c}\text { Partisipan } \\
\mathbf{4}\end{array}$ & $\begin{array}{c}\text { Partisipan } \\
\mathbf{5}\end{array}$ & TOTAL \\
\hline 1 & Tekstual & 7 & 8 & 15 & 11 & 12 & 54 \\
\hline 2 & Grammatical & 8 & 8 & 16 & 12 & 14 & 58 \\
\hline 3 & Pragmatic & 2 & 1 & 2 & 2 & 2 & 9 \\
\hline
\end{tabular}
tidak antara bahasa sumber (BS) dan bahasa target (BT). Didalam penelitian ini, peneliti meneliti 5 partisipan sebagai penerjemah. Berdasarkan rumusan masalah nomer dua, peneliti akan mempresentasikan contoh dari data mengenai kesetaraan dalam penerjemahan berdasakan teori Baker (1992) yang diketemukan dalam hasil penerjemahan. Baker (1992) membagi menjadi 3 kesetaraan dalam penerjemahan, yaitu kesetaraan gramatikal, kesetaraan tekstual, dan kesetaraan pragmatik. Peneliti menemukan 2 kesetaraan penerjemahan yang diambil dari hasil terjemahan dari 5 partisipan berdasarkan teori Baker. Setiap partisipan berhasil mencapai dua jenis dari kesetaraan untuk membuat bahasa target memudahkan untuk dipahami. bahasa sumber (BS). Apakah setara atau 
FON ; Jurnal Pendidikan Bahasa dan Sastra Indonesia

Volume 12 Nomor 1 Tahun 2018

Berdasarkan tabel data diatas, partisipan dua terdapat 1 kesetaraan, partisipan-partisipan dari penelitian ini sedangkan pada penerjemahan partisipan sukses mencapai kesetaraan tekstual dan tiga, empat dan lima terdapat masingkesetaraan gramatikal. Kesetaraan masing 2 kesetaraan.

didalam penerjemahan adalah sebuah hal

Berdasarkan pertanyaan penelitian yang diperlukan, pembaca mengerti atau tidak terhadap hasil dari penerjemahan hal nomer dua dan data, peneliti akan mempresentasikan contoh dari data tersebut tergantung dari setara atau tidak antara bahasa sumber (BS) dan bahasa target (BT). Kesetaraan tekstual ditemukan lebih dari 54 kali di dalam hasil terjemahan oleh partisipanpartisipan, partisipa lima 12 kali mencapai kesetaraan tekstual didalam penelitian, sedangkan partisipan satu mencapai 7 kali. Partisipan tiga membuat 15 kali kesetaraan tekstual, partisipan dua dan partisipan empat membuat 20 kesetaraan. Total jumlah kesetaraan grammatikal yang diketemukan didalam data adalah 58 . Terdapat 8 kesetaraan gramatikal didalam penerjemahan dari partisipan satu, dalam partisipan dua terdapat 8 kesetaraan, pada penerjemhan partisipan tiga terdapat 16 , partisipan empat terdapat 12 kesetaraan dan patisipan lima mencapai 14 mengenai jenis-jenis kesetaraan berdasarkan teori Baker (1992) yang digunakan oleh para mahasiswa yang sebagai partisipan dari penelitian.

\section{KESIMPULAN}

Dua pertanyaan pada rumusan masalah telah terjawab, pertanyaan yang pertama adalah bagaimana para partisipan dalam menerjemahkan kata-kata slang didalam dialog terdapat dalam. Berdasarkan hasil penerjemahan yang dilakukan oleh para partispan kata slang yang berjumlah 12 hanya terdapat 6 kata yang bisa di terjemahkan dengan baik oleh para partisipan dalam penerjemahan ini. Sedangkan untuk pertanyaan kedua mengenai kesetaraan didalam penerjemahan, terdapat 54 kesetaraan kesetaraan gramatikal. Didalam tekstual, 58 kesetaraan gramatikal dan 9 kesetaraan pragmatik terdapat total 9 kesetaraan yang diketemukan dalam kesetaraan pragmatikal.

penerjemahan ke lima partisipan tersebut, penerjemahan yang dilakukan oleh para partisipan satu terdapat 2 kesetaraan. partisipan dalam penelitian ini, bisa Dalam penerjemahan yang dilakukan oleh diambil sebuah kesimpulan bahwa 
FON ; Jurnal Pendidikan Bahasa dan Sastra Indonesia

Volume 12 Nomor 1 Tahun 2018

sebagian besar partisipan masih kesulitan dalam menerjemahkan kata-kata slang tersebut. Sebagian besar dari partisipan tidak mengetahui bahwa kata-kata tersebut merupakan kata-kata slang, dan apabila mereka mengetahui makna dari kata-kata slang tersebut, sebagian dari partisipan kesulitan dalam menemukan kata-kata yang tepat dalam bahasa Indonesia untuk menerjemahkan kata-kata tersebut

\section{DAFTAR PUSTAKA}

Abdel-daem, Mohamed Kamel. (2013). Translation of present-day Egyptian slang into English, IOSR Journal of Humanities and Social Science, 15(1), 60-65.

Bell, Roger T. (1991). Translation and Translating: Theory and Practice. London: Longman.

Brodwell, D, Thompson, K. (2008). Film Art :Introduction, eight edition. New York: McGraw-Hill Company.

Catford, J. C. (1965). A Linguistic Theory of Translation. London: Oxford University Press.

Creswell, John W. (1998). Qualitative Inquiry and Research Design: Gerot, Linda and Wignell, Peter. (1994). Making Sense of Functional Grammar. Sydney: GerdStabler.

Klarer, Mario (1998). An Introduction to Literary Studies. London: Routledge Larson, Mildred L. (1984). MeaningBased Translation: A Guide to Cross Language Equivalence. New York: University Press of America.

Newmark, Peter. (1988). A Textbook of Tranlation. London: Prentice Hall.

Nugraha, Kartika. (2013). The comparative analysis on the translation of slang words the subtitle of the movie Fired up between DVD and internet versions, Diglosia, 4(2).

Choosingamon Five Traditions.

Thousand Oaks, CA: Sage. 
FON ; Jurnal Pendidikan Bahasa dan Sastra Indonesia

Volume 12 Nomor 1 Tahun 2018

Nida, Eugene A. (1969). Toward A Yuliana, Tiarma Ika. (21014). The Science of Translation. Leiden: translation of English slang words in E.J.Brill.

Vassiliou, A. (2006). Analysis Film Content: a text-based approach. Shidney Sheldon "Nothing last forever". E-journa Gunadarma 8 Department of Computing School of Electronoc and Physical Sciences, University of Surrey. Guildford: UK. (6), 16-19.

Yusuf, Drs. Suhendra Yusuf, M.A. (1994). Teori Terjemah Pengantar ke Arah Pendekatan Linguistik dan Sosialinguistik. Penerbit Mandar Maju. Bandung 